\title{
The Relationship Between Multiple Intelligences and Language Learning Strategies and Gender
}

\author{
Ali Akbar Ansarin ${ }^{1} \&$ Samira Paki Khatibi ${ }^{1}$ \\ ${ }^{1}$ University of Tabriz, Tabriz, Iran \\ Correspondence: Samira Paki Khatibi, University of Tabriz, Tabriz, Iran. E-mail: s.pakikhatibi@gmail.com
}

Received: October 19, 2017 Accepted: April 19, 2018 Online Published: April 21, 2018

doi: 10.5539/elt.v11n5p84 URL: http://doi.org/10.5539/elt.v11n5p84

\begin{abstract}
This study set out with the aim of assessing whether Multiple Intelligences profiles of Iranian students would exert any influence on their use of language learning strategies as important determining factors in the language learning. Additionally, we explored the role of gender and different proficiency levels on EFL learners' multiple intelligences. A total number of 303 EFL learners, 164 males and 139 females participated in this study, 112 were Elementary, 92 were Intermediate students and 99 were advanced level, within the age range of 12 to 33 at Jahade Daneshgahi of Tabriz. The instruments used to elicit information for this study were MIDAS and the Strategy Inventory for Language Learning (SILL) Questionnaire. Initially, we homogenized the English proficiency of the participants, by administering Nelson English Language Tests. Results showed a significant relationship between the variables of multiple intelligences (MI) and Strategy Inventory of Language Learning (SIL). Results of multivariate tests showed a significant positive difference between the MI scores and different proficiency levels but no significant difference in MI scores across genders. a significant difference was found in musical intelligence of participants at different proficiency levels. In terms of implications of the study it is suggested that before choosing any teaching materials, educators should conduct needs analysis and test in order to find out the MI profile of the students and to avoid having any mismatch between selected topics and the students' needs.
\end{abstract}

Keywords: language learning strategies, intelligence, multiple intelligences

\section{Introduction}

Recently multiple intelligences theory attracted the attention of many researchers in education-related contexts. L2 learners with distinct individual differences can employ strategies differently. Thus, it can be beneficial to recognize the individual factors that facilitate L2 learners' strategy use, given that the link between language learning strategy use and language achievement is strong (O'Mally \& Chamot, 1990). A major problem in EFL classes is that learners' individual differences are not usually taken into consideration in language instruction. Drawing on the theory of Multiple Intelligences, the study tried to find out whether IQ indices have any relationship with the learners' use of language learning strategies. This study attempted to investigate the role of gender and language proficiency in the EFL learners' MI profiles.

The objectives of this study were three-fold. The major objective of the study was to shed light on the role of language learning strategies and its relationship to intelligence type. This study was inspired by Gardner's MIT and the possible role that this theory can play in explaining the successful L2 learners' use of language learning strategies. Furthermore, the present study explored the role of gender and different proficiency levels across students with various intelligence types.

\subsection{Importance of the Problem}

Investigating the use of language learning strategies and intelligence type of EFL learners will allow us to make more informed decisions concerning how they should be dealt with in language classes. Thus, teachers should take into account different intelligences of the students and prepare student-centered activities that apply all the students' intelligences. Kagan and Kagan (1998) stated that students recognize their own pattern of intelligences and that of their classmates. Students come to celebrate their own uniqueness and honor the diversity they discover among themselves. Thus, recognizing the students' intelligences and learning in a conductive environment are vital for effective learning to take place. 


\subsection{The Theory of Multiple Intelligences}

According to Gardner (1998), intelligence is described as "a psychobiological potential to solve problems or to fashion products that are valued in at least one cultural context" (p. 20). The importance of multiple intelligences in education lies in the fact that learners differ in their abilities, and therefore teachers need to understand the best strategies to apply according to their variations, or to establish programs that direct the learners in different domains.

\subsection{Gardner's Categories of Intelligences}

Gardner (1999) described each of the eight intelligences by using biological and cultural research. These intelligences are as follows:

\subsubsection{Verbal/Linguistic Intelligence}

Verbal/Linguistic Intelligence is defined as the capacity to use words effectively, whether orally or in writing. (Armstrong, 2000; Gardner, 1999).

\subsubsection{Logical/Mathematical Intelligence}

Gardner (2007) referred to logical-mathematical intelligence as the ability to sequence things and work with numbers.

\subsubsection{Visual/ Spatial Intelligence}

Smith (2008) argued that spatial intelligence involves the potential to recognize and use the patterns.

\subsubsection{Musical/Rhythmic Intelligence}

Smith (2008) argued that musical intelligence includes the ability in the performance, composition, and appreciation of musical patterns.

\subsubsection{Bodily/Kinesthetic Intelligence}

Gardner (1999) defined this intelligence as the ability of using the whole body or parts of the body in problem-solving or the creation of products.

\subsubsection{Interpersonal Intelligence}

According to Smith (2008) Interpersonal Intelligence was related to the capacity in understanding the intentions, motivations, and interests of other people.

\subsubsection{Intrapersonal intelligence}

According to Armstrong (2000) intrapersonal intelligence is the capacity for self-awareness and the ability to access effectively one's inner feelings, values and beliefs.

\subsubsection{Naturalistic Intelligence}

Gardner (1999) argued that naturalistic intelligence involved the human ability to distinguish among living things and to organize, identify and categorize (e.g. plants, animals).

\subsubsection{Existential Intelligence}

Gardner (1995) argued that those who have existential intelligence are concerned with questions related to the human conditions like the meaning of life, death, and love.

\subsection{Definition of Language Learning Strategies}

Oxford (1990) claimed that "L2 strategies are specific actions taken by the learner to make learning easier, faster, more enjoyable, more self-directed, more effective and more transferable to new situations" (p. 8).

\subsubsection{Oxford's Classification of Language Learning Strategies}

Oxford (1990) classified language learning strategies into two major classes: direct and indirect according to how they involve the target language. Direct and indirect strategies are described below:

\subsubsection{Direct Strategies}

Direct strategies (memory, cognitive, and compensation) are strategies students use to directly manipulate the information received for learning, retaining and recalling prior information (Oxford, 1990).

1) Memory Strategies: Oxford and Crookall (1989, p. 404) defined memory strategies as "techniques specifically tailored to help the learner store new information in memory and retrieve it later". 
2) Cognitive Strategies: Cognitive strategies fall into four sets: Practicing, receiving and sending messages, analyzing and reasoning, and creating structure for input and output. (Oxford, 1990).

3) Compensation Strategies: The objectives of compensation strategies strategies are to make up for a limited repertoire of grammar and especially vocabulary (Oxford, 1990).

\subsubsection{Indirect Strategies}

Indirect strategies include three subcategories: metacognitive, affective, and social strategies (Oxford, 1990, p.55).

1) Metacognitive Strategies: Metacognitive strategies are described as "behaviors used for centering, arranging, planning and evaluating one's learning. These 'beyond the cognitive' strategies are used to provide 'executive control over the learning process' " (Oxford \& Crookall, 1989, p. 404).

2) Affective Strategies: Affective strategies enhance the self-confidence and perseverance required for learners to engage themselves in language learning (Oxford, 1990).

3) Social Strategies: Social strategies provide increased interaction and more empathetic understanding since they occur among and between people (Canale, 1983).

\subsection{Some Related Studies on Multiple Intelligences and Language Learning Strategies}

There are a number of studies relating to the multiple intelligences and language learning strategies. Akbari and Hosseini (2008) indicated a significant positive correlation between multiple intelligences score and language learning strategies. The findings of Akbari and Talebinezhad (2003) indicated that there was a positive relationship between the use of LLS and students' proficiency scores. Compensatory strategies were also found as the best predictor of language proficiency. No significant relationship was found between the participants' strategy use and their IQ scores. Hashemian and Adibpour (2012) showed a strong positive relationship between multiple intelligences and language learning strategies.

According to Pishghadam and Moafian (2008), there was a significant relationship between Iranian EFL teachers' success and their musical, kinesthetic and interpersonal intelligences, but there was no significant relationship between teachers' success and other types of intelligences. Moreover, there were not any significant differences between gender and MI in terms of teaching success. In the same line, Razmjoo (2008) suggested that generally there is not any significant relationship between language proficiency and multiple intelligences in particular. Similarly, there is not any significant difference between male and female students and between their MI and language proficiency.

In another study, Razmjoo, Sahragard, and Sadri (2009) reported a relationship between MI and EFL learners' vocabulary learning knowledge and vocabulary learning strategies. Bemani Naieni and Pandian (2010) reported that there was not significant relationship between MI profiles and listening comprehension. Likewise, the findings showed that there was no significant difference between MIs and attitudes.

Baş and Beyhan (2010) proposed that the multiple intelligences approach activities were more influential in the positive development of the students' attitudes. Moreover, the results showed that the students who were educated by multiple intelligences supported project-based learning method were well-performed in comparison with students who were educated by the traditional instructional methods.

According to Pasha Sharifi (2008), there was low to moderate but significant correlation among different kinds of intelligence and related school subject scores. They also found that the female students had superiority compared to males in the intrapersonal intelligence area, while the male students had superiority in visual-spatial intelligence. There was no significant difference in terms of other types of intelligence between the two genders.

Chen (2009) showed that there was a significant relationship between grade level and kinesthetic learning style preference, tactile learning style preference and individual learning style preference. He found that there were significant relationships among grade level and the use of memory strategies, cognitive strategies and metacognitive strategies affective strategies and social strategies. Grainger (2005) also proposed that the beginning learners of Japanese scored higher on most literacy-related strategy items contained in the SILL.

Leavell and Hong-Nam (2006) came into conclusion that there was a significant relationship between strategy use and English proficiency. The results also indicated that intermediate students used learning strategies more than beginners, and advanced students. Metacognitive strategies were the most frequently used strategies and affective and memory strategies were the least preferred categories. Moreover, females used affective and social strategies with a higher frequency than males.

Magogwe and Oliver (2007) argued that the use of language learning strategies differed significantly in terms of 
their preferences for particular types of strategies. Moreover, findings revealed that there was a significant relationship between preferred language strategies, age, proficiency and self-efficacy beliefs.

Aliakbari \& Hayatzadeh (2008) indicated that Iranian English students employed learning strategies at high and medium frequency level. Although male students reported higher frequency of strategy use than female students, statistical analysis of t-test confirmed that gender difference was not one of the variables contributing to the differences in the choices of language learning strategies.

Khamkhien (2010) showed that motivation was the most significant factor affecting the choice of the strategies, followed by experience in studying English, and gender. The results revealed that gender had no significant role in the use of the strategies.

Rezaei and Almasian (2007) examined whether there was any relationship between creativity, strategy use and language proficiency. The findings suggested that creativity and degree of strategy use and also creativity and language proficiency were significantly correlated; but the degree of strategy use and language proficiency did not show any relationship.

Shmais (2003) found out that students' learning strategy use as measured by the SILL ranged from high (3.98) to medium (3.15), with metacognitive strategies being used more frequently. Moreover, gender and proficiency had no significant differences on the use of strategies.

Yang and Oxford (1997) reported that males and females used similar strategies to process the Spanish and English passages. Ehrman and Oxford (1989) found out that females used social strategies more than males. Also, they concluded that higher levels of English language proficiency often used greater strategy.

Peacock and Ho (2003) reported that a positive association was found between 27 strategies and proficiency. Females were strong in the use of memory and metacognitive areas and older students in affective and social strategies.

Wharton (2000) reported significant gender differences, favoring males, in students' strategy use and more strategies used significantly more often with higher proficiency.

Tercanliglu (2004) found out that males used learning strategy more than females. Green and Oxford (1995) concluded that higher levels of proficiency used more language learning strategies and females used strategies more than males.

\subsection{Research Questions and Hypotheses}

\subsubsection{Research Questions}

More specifically, the following research questions and hypotheses were addressed:

Research Question one: Is there any relationship between EFL learners' Multiple Intelligences (MI) scores and their use of different language learning strategies?

Null Hypothesis 1: There is no relationship between EFL learners' Multiple Intelligences (MI) scores and their use of different language learning strategies.

Alternative Hypothesis 1: There is a relationship between EFL learners' Multiple Intelligences (MI) scores and their use of different language learning strategies.

Research Question 2: Is there any relationship between EFL learners' Multiple Intelligences (MI) scores and different proficiency levels and gender?

Null Hypothesis 2: There is no relationship between EFL learners' Multiple Intelligences (MI) scores and different proficiency levels and gender.

Alternative Hypothesis 2: There is a relationship between EFL learners' Multiple Intelligences (MI) scores and different proficiency levels and gender.

\section{Method}

\subsection{Participants}

The present study was conducted at Jahade Daneshgahi English Language Institute in Tabriz, Iran. A total number of 303 EFL learners, 164 males and 139 females, within the age range of 12 to 33 participated in this study. All participants were from elementary, intermediate and advanced levels. They enrolled in English language classes at Jahade Daneshgahi in Tabriz in fall 2013. 


\subsection{Sampling Procedures}

The data were collected in three stages during three weeks in 2013. In stage one, the proficiency test was administered to the 303 EFL learners at Jahade Daneshgahi English Language Institute in Tabriz, Iran. In stage two, MIDAS was administered to the participants to find out their MI Profiles. Finally, SILL was administered to the participants to find out about their strategy use. The data in stages two and three were collected in two sessions within a week after collecting the needed data on the participants' English proficiency.

To determine the language proficiency of the participants, Nelson English Language Tests (Flower \& Coe, 1976) were administered to divide the participants into elementary, intermediate, and advanced proficiency levels. "All the items in these tests have been carefully pretested." (Flower \& Coe, 1976, p. 8) and for each level four equivalent tests were specified.

To determine the participants' multiple intelligences scores, (Multiple Intelligences Developmental Assessment Scales) $M I D A S$ was used. MIDAS is a valid questionnaire to explore participants' multiple intelligences (Shearer, 1994). In the present study, the translated version of MIDAS was used for elementary level learners. The Cronbach alpha reliability of the translated version of MIDAS was considered to be 0.85 .

Oxford's (1990) Strategy Inventory for Language Learning (SILL) has been the most widely used questionnaire on the strategy usage of EFL learners. A version of SILL (50 items), which was designed for ESL/EFL learners, was utilized in this paper. In the present study, the translated version of SILL was used for elementary level learners. Cronbach alpha for this translated version was found to be 0.81. Language learning strategies and multiple intelligences were independent variables in this study.

\subsection{Design of the Study}

The design of the present study was considered as survey. So two types of questionnaires dealing with language learning strategies and multiple intelligences were given to the participants.

\section{Results}

\subsection{Statistics and Data Analysis}

\subsubsection{Research Question One}

To explore the first research question concerning the (possible) relationship between the participants' MI scores and their LLSs use, Pearson-Product Moment Correlation Test was used between the MI scores and the participants' LLSs use. As depicted in Table 1, certain relationships were found between MI scores and LLS. There was a significant positive correlation $(\mathrm{p}<0.05)$ between the musical intelligence and metacognitive strategies. Besides, there was a significant positive correlation $(\mathrm{p}<0.05)$ between the kinesthetic intelligence and (total strategies) LLS, memory strategies, cognitive strategies, metacognitive strategies, and social strategies. Math/Logic, spatial, linguistic, interpersonal and intrapersonal intelligences had a positive significant correlation ( $p<0.05$ ) with (total strategies) LLS, memory, cognitive, compensation, metacognitive, affective, social strategies. Furthermore, the naturalistic intelligence had a positive correlation with the total strategies (LLS), memory, cognitive, compensation, metacognitive, affective strategies.

Table 1. Correlations between different intelligences and different strategy types

\begin{tabular}{llllllll}
\hline & LLS & $\begin{array}{l}\text { Memory } \\
\text { Strategies }\end{array}$ & $\begin{array}{l}\text { Cognitive } \\
\text { Strategies }\end{array}$ & $\begin{array}{l}\text { Compensation } \\
\text { Strategies }\end{array}$ & $\begin{array}{l}\text { Meta } \\
\text { cognitive } \\
\text { Strategies }\end{array}$ & $\begin{array}{l}\text { Affective } \\
\text { Strategies }\end{array}$ & $\begin{array}{l}\text { Social } \\
\text { Strategies }\end{array}$ \\
\hline MUSICAL & .043 & .022 & .024 & .009 & $.174^{* *}$ & -.038 & .044 \\
KINESTHETIC & $.160^{* *}$ & $.141^{*}$ & $.158^{* *}$ & .086 & $.155^{* *}$ & .069 & $.131^{*}$ \\
MATH / LOGIC & $.318^{* *}$ & $.278^{* *}$ & $.241^{* *}$ & $.187^{* *}$ & $.300^{* *}$ & $.190^{* *}$ & $.266^{* *}$ \\
SPATIAL & $.294^{* *}$ & $.174^{* *}$ & $.282^{* *}$ & $.213^{* *}$ & $.252^{* *}$ & $.207^{* *}$ & $.208^{* *}$ \\
LINGUISTIC & $.385^{* *} .339^{* *}$ & $.276^{* *}$ & $.240^{* *}$ & $.323^{* *}$ & $.266^{* *}$ & $.317^{* *}$ \\
INTERPERSONAL & $.345^{* *} .246^{* *}$ & $.258^{* *}$ & $.253^{* *}$ & $.314^{* *}$ & $.240^{* *}$ & $.269^{* *}$ \\
INTRAPERSONAL & $.343^{* *} .244^{* *}$ & $.257^{* *}$ & $.166^{* *}$ & $.362^{* *}$ & $.243^{* *}$ & $.290^{* *}$ \\
NATURALISTIC & $.150^{* *}$ & $.136^{*}$ & $.146^{*}$ & .071 & $.152^{* *}$ & $.119^{*}$ & .054
\end{tabular}

Note. Participants $(\mathrm{N}=303) ; * *$ correlation is significant at $(0.01)$ level; $*$ correlation is significant at $(0.05)$; LLS=language learning strategy. 
To find out whether learners at differet proficiency levels (elemantary, intermediate and advanced) made different use of language learning strategies and multiple intelligences, the strategies and multiple intelligences of each proficiency group were calculated as reported in Tables 2, 3, and 4.

To further analyze the data, correlations between MI and total strategy use scores as well as correlations between MI and individual strategy type scores at the elemantary level were calculated using Pearson product moment correlational analysis. As Table 4.2 reveals, positive significant correlation was found between musical intelligence and metacognitive strategies. Furthermore, there was a significant positive correlation between the kinesthetic intelligence and (total strategies) LLS, memory strategies, cognitive strategies and compensation strategies. Math/ Logic, spatial, linguistic, interpersonal intelligences had a positive correlation with LLS, memory, cognitive, compensation, metacognitive, affective, social strategies. Also, the intrapersonal intelligence had the positive correlation with the total strategies (LLS), memory, cognitive, metacognitive, affective, and social strategies. Finally, naturalistic intelligence showed a positive correlation with the total strategies (LLS), memory, cognitive, metacognitive, and affective strategies.

Table 2. Correlation between different intelligences and different strategy types of elementary participants

\begin{tabular}{llllllll}
\hline & LLS & $\begin{array}{l}\text { Memory } \\
\text { Strategies }\end{array}$ & $\begin{array}{l}\text { Cognitive } \\
\text { Strategies }\end{array}$ & $\begin{array}{l}\text { Compensation } \\
\text { Strategies }\end{array}$ & $\begin{array}{l}\text { Meta } \\
\text { cognitive } \\
\text { Strategies }\end{array}$ & $\begin{array}{l}\text { Affective } \\
\text { Strategies }\end{array}$ & $\begin{array}{l}\text { Social } \\
\text { Strategies }\end{array}$ \\
\hline MUSICAL & .096 & .097 & .065 & -.032 & $.255^{* *}$ & -.051 & .143 \\
KINESTHETIC & $.233^{*}$ & $.205^{*}$ & $.253^{* *}$ & $.192^{*}$ & .173 & .164 & .149 \\
MATH / LOGIC & $.420^{* *}$ & $.336^{* *}$ & $.380^{* *}$ & $.253^{* *}$ & $.348^{* *}$ & $.265^{* *}$ & $.400^{* *}$ \\
SPATIAL & $.349^{* *}$ & $.207^{*}$ & $.337^{* *}$ & $.221^{*}$ & $.315^{* *}$ & $.284^{* *}$ & $.292^{* *}$ \\
LINGUISTIC & $.448^{* *}$ & $.435^{* *}$ & $.371^{* *}$ & $.224^{*}$ & $.378^{* *}$ & $.280^{* *}$ & $.410^{* *}$ \\
INTERPERSONAL & $.411^{* *}$ & $.335^{* *}$ & $.355^{* *}$ & $.239^{*}$ & $.345^{* *}$ & $.320^{* *}$ & $.339^{* *}$ \\
INTRAPERSONAL & $.368^{* *}$ & $.323^{* *}$ & $.294^{* *}$ & .113 & $.364^{* *}$ & $.256^{* *}$ & $.386^{* *}$ \\
NATURALISTIC & $.271^{* *}$ & $.277^{* *}$ & $.285^{* *}$ & .100 & $.208^{*}$ & $.247^{* *}$ & .138 \\
\hline
\end{tabular}

Note. Participants $(\mathrm{N}=112) ;{ }^{* *}$ correlation is significant at $(0.01)$ level; *correlation is significant at $(0.05)$; LLS=language learning strategy.

Similar analysis were done at the intermediate level group. As Table 3 illustrates the musical, kinesthetic, math/logic, naturalistic intelligences had no significant correlations with any of the strategies while positive correlations existed between spatial intelligence, cognitive and compensation strategies. Additionally, linguistic intelligence had the positive correlations with the total strategies (LLS), cognitive, metacognitive strategies, and social strategies. Moreover, interpersonal intelligence had a positive correlation with the total strategies (LLS), compensation and metacognitive strategy. Finally, intrapersonal intelligence had a positive significant correlation with the total strategies (LLS), cognitive, and metacognitive strategies.

Table 3. Correlations between different intelligences and different strategy types of intermediate participants

\begin{tabular}{llllllll}
\hline & LLS & $\begin{array}{l}\text { Memory } \\
\text { Strategies }\end{array}$ & $\begin{array}{l}\text { Cognitive } \\
\text { Strategies }\end{array}$ & $\begin{array}{l}\text { Compensation } \\
\text { Strategies }\end{array}$ & $\begin{array}{l}\text { Meta cognitive } \\
\text { Strategies }\end{array}$ & $\begin{array}{l}\text { Affective } \\
\text { Strategies }\end{array}$ & $\begin{array}{l}\text { Social } \\
\text { Strategies }\end{array}$ \\
\hline MUSICAL & .064 & .078 & .199 & .186 & -.019 & -.012 & -.072 \\
KINESTHETIC & .153 & .089 & .205 & .057 & .197 & .024 & .081 \\
MATH / LOGIC & .164 & .146 & .168 & .151 & .167 & .015 & .087 \\
SPATIAL & .182 & .093 & $.212^{*}$ & $.264^{*}$ & .186 & .032 & .012 \\
LINGUISTIC & $.293^{* *}$ & .165 & $.221^{*}$ & .197 & $.306^{* *}$ & .152 & $.212^{*}$ \\
INTERPERSONAL & $.240^{*}$ & .055 & .148 & $.281^{* *}$ & $.317^{* *}$ & .083 & .150 \\
INTRAPERSONAL & $.267^{*}$ & .030 & $.216^{*}$ & .142 & $.315^{* *}$ & .201 & .203 \\
NATURALISTIC & -.029 & -.053 & -.037 & .054 & .096 & -.039 & -.118 \\
\hline
\end{tabular}

Note. Participants $(\mathrm{N}=92)$; ** correlation is significant at $(0.01)$ level; *correlation is significant at $(0.05)$; 
LLS=language learning strategy.

Finally, at the advanced level,we run the above mentioned test. As table 4 reveals, among the intelligences, musical and naturalistic intelligences had no significant correlation with any strategy. In addition, kinesthetic intelligence revealed a positive significant correlation with social strategy. Math/ Logic, linguistic, interpersonal, intrapersonal intelligences had positive correlations with the (total strategies) LLS, memory, cognitive, compensation, metacognitive, affective, and social strategies. Spatial intelligence showed a positive correlation with the (total strategies) LLS, memory, cognitive, metacognitive, affective and social strategies. So there is a relationship between EFL learners' Multiple Intelligences (MI) scores and their use of different language learning strategies.

Table 4. Correlations between different intelligences and different strategy types of advanced participants

\begin{tabular}{llllllll}
\hline & LLS & $\begin{array}{l}\text { Memory } \\
\text { Strategies }\end{array}$ & $\begin{array}{l}\text { Cognitive } \\
\text { Strategies }\end{array}$ & $\begin{array}{l}\text { Compensation } \\
\text { Strategies }\end{array}$ & $\begin{array}{l}\text { Meta cognitive } \\
\text { Strategies }\end{array}$ & $\begin{array}{l}\text { Affective } \\
\text { Strategies }\end{array}$ & $\begin{array}{l}\text { Social } \\
\text { Strategies }\end{array}$ \\
\hline MUSICAL & .058 & -.059 & .058 & .087 & .075 & .052 & .122 \\
KINESTHETIC & .087 & .116 & .044 & .001 & .060 & -.007 & $.206^{*}$ \\
MATH / LOGIC & $.366^{* *}$ & $.376^{* *}$ & $.235^{*}$ & $.251^{*}$ & $.296^{* *}$ & $.316^{* *}$ & $.326^{* *}$ \\
SPATIAL & $.327^{* *}$ & $.205^{*}$ & $.319^{* *}$ & .179 & $.250^{*}$ & $.275^{* *}$ & $.320^{* *}$ \\
LINGUISTIC & $.392^{* *}$ & $.362^{* *}$ & $.236^{*}$ & $.353^{* *}$ & $.290^{* *}$ & $.375^{* *}$ & $.316^{* *}$ \\
INTERPERSONAL & $.375^{* *}$ & $.314^{* *}$ & $.298^{* *}$ & $.330^{* *}$ & $.262^{* *}$ & $.311^{* *}$ & $.331^{* *}$ \\
INTRAPERSONAL & $.393^{* *}$ & $.328^{* *}$ & $.302^{* *}$ & $.346^{* *}$ & $.393^{* *}$ & $.294^{* *}$ & $.254^{*}$ \\
NATURALISTIC & .145 & .100 & .183 & .116 & .079 & .102 & .139 \\
\hline
\end{tabular}

Note. Participants $(\mathrm{N}=99) ; * *$ correlation is significant at $(0.01)$ level; *correlation is significant at $(0.05)$;

LLS=language learning strategy.

\subsubsection{Research Question Two}

To address the second research question dealing with the relationship between the MI scores and different proficiency levels and gender, a two-way MANNOVA was conducted. In order to examine MI scores at different proficiency levels, Hotelling's Trace was run. As Table 5 reveals, Hotelling's Trace value $=0.116$, F-ratio $=2.096$ and $\mathrm{p}=0.007(\mathrm{p}<0.05)$. The results of Multivariate tests showed a significant difference between the MI scores and different proficiency levels. As Table 5 reveals, Hotelling's Trace value $=0.037$, F-ratio $=1.336$ and $\mathrm{p}=0.225$ $(\mathrm{p}>0.05)$. The results of Multivariate tests revealed there was no significant difference between two groups in regard to MI scores. In sum, there was no significant difference in interaction of the Multivariate tests of MI scores between different proficiency levels and gender.

The results of analysis of univariate test indicated that there was a significant difference in musical intelligence of participants at different proficiency levels. Moreover, no significant difference was observed in other intelligences across the three proficiency levels. However, no significant difference in MI was observed between male and female participants. Furthermore, there was no significant difference in interaction of univariate test of multiple intelligences between male and female participants at different proficiency levels. The results are reported in Table 6.

Besides, for performing paired comparison between the study groups, LSD test was used. See Table 7. The results showed that compared with the other groups, the elementary level acquired statistically the highest musical intelligence. So there is a relationship between EFL learners' Multiple Intelligences (MI) scores and different proficiency levels. 
Table 5. Two-way MANOVA of MI at different proficiency levels and gender (multivariate tests)

\begin{tabular}{llllllll}
\hline Effect & & Value & $\mathrm{F}$ & Hypothesis df & Error df & Sig. & Partial Eta Squared \\
\hline \multirow{4}{*}{ Intercept } & Pillai's Trace & .972 & $1266.864^{\mathrm{a}}$ & 8.000 & 290.000 & .000 & .972 \\
& Wilks' Lambda & .028 & $1266.864^{\mathrm{a}}$ & 8.000 & 290.000 & .000 & .972 \\
& Hotelling's Trace & 34.948 & $1266.864^{\mathrm{a}}$ & 8.000 & 290.000 & .000 & .972 \\
& Roy's Largest Root & 34.948 & $1266.864^{\mathrm{a}}$ & 8.000 & 290.000 & .000 & .972 \\
\hline \multirow{5}{*}{ Group } & Pillai's Trace & .107 & 2.065 & 16.000 & 582.000 & .009 & .054 \\
& Wilks' Lambda & .894 & $2.081^{\mathrm{a}}$ & 16.000 & 580.000 & .008 & .054 \\
& Hotelling's Trace & .116 & 2.096 & 16.000 & 578.000 & .007 & .055 \\
& Roy's Largest Root & .094 & $3.435^{\mathrm{b}}$ & 8.000 & 291.000 & .001 & .086 \\
\hline \multirow{5}{*}{ Gender } & Pillai's Trace & .036 & $1.336^{\mathrm{a}}$ & 8.000 & 290.000 & .225 & .036 \\
& Wilks' Lambda & .964 & $1.336^{\mathrm{a}}$ & 8.000 & 290.000 & .225 & .036 \\
& Hotelling's Trace & .037 & $1.336^{\mathrm{a}}$ & 8.000 & 290.000 & .225 & .036 \\
& Roy's Largest Root & .037 & $1.336^{\mathrm{a}}$ & 8.000 & 290.000 & .225 & .036 \\
\hline \multirow{3}{*}{ Group * } & Pillai's Trace & .071 & 1.334 & 16.000 & 582.000 & .171 & .035 \\
Gender & Wilks' Lambda & .930 & $1.337^{\mathrm{a}}$ & 16.000 & 580.000 & .169 & .036 \\
& Hotelling's Trace & .074 & 1.339 & 16.000 & 578.000 & .167 & .036 \\
& Roy's Largest Root & .058 & $2.102^{\mathrm{b}}$ & 8.000 & 291.000 & .036 & .055 \\
\hline
\end{tabular}

Note. $\mathrm{a}=$ exact statistic; $\mathrm{b}=$ the statistic is an upper bound on $\mathrm{F}$ that yields a lower bound on the significance level; $\mathrm{c}=$ design: intercept + group + gender + group $*$ gender.

Table 6. Two-way MANOVA OF MI at different proficiency levels and gender (univariate test)

\begin{tabular}{|c|c|c|c|c|c|c|c|c|c|c|}
\hline Source & & Dependent Variable & $\begin{array}{l}\text { Type III } \\
\text { Squares }\end{array}$ & Sum & of $\mathrm{df}$ & $\begin{array}{l}\text { Mean } \\
\text { Square }\end{array}$ & $\mathrm{F}$ & Sig. & $\begin{array}{l}\text { Partial } \\
\text { Squared }\end{array}$ & Eta \\
\hline \multirow[t]{8}{*}{ Group } & & MUSICAL & 3908.744 & & 2 & 1954.372 & 10.608 & .000 & .067 & \\
\hline & & KINESTHETIC & 188.934 & & 2 & 94.467 & .561 & .571 & .004 & \\
\hline & & MATH / LOGIC & 626.906 & & 2 & 313.453 & 1.733 & .179 & .012 & \\
\hline & & SPATIAL & 90.421 & & 2 & 45.210 & .236 & .790 & .002 & \\
\hline & & LINGUISTIC & 31.958 & & 2 & 15.979 & .118 & .889 & .001 & \\
\hline & & INTERPERSONAL & 243.270 & & 2 & 121.635 & .697 & .499 & .005 & \\
\hline & & INTRAPERSONAL & 377.583 & & 2 & 188.792 & .819 & .442 & .005 & \\
\hline & & NATURALISTIC & 709.372 & & 2 & 354.686 & 1.561 & .212 & .010 & \\
\hline \multirow[t]{8}{*}{ Gender } & & MUSICAL & 108.011 & & 1 & 108.011 & .586 & .444 & .002 & \\
\hline & & KINESTHETIC & 422.868 & & 1 & 422.868 & 2.510 & .114 & .008 & \\
\hline & & MATH / LOGIC & 253.627 & & 1 & 253.627 & 1.402 & .237 & .005 & \\
\hline & & SPATIAL & 44.574 & & 1 & 44.574 & .233 & .630 & .001 & \\
\hline & & LINGUISTIC & 48.917 & & 1 & 48.917 & .361 & .549 & .001 & \\
\hline & & INTERPERSONAL & 106.904 & & 1 & 106.904 & .613 & .434 & .002 & \\
\hline & & INTRAPERSONAL & .037 & & 1 & .037 & .000 & .990 & .000 & \\
\hline & & NATURALISTIC & 645.271 & & 1 & 645.271 & 2.839 & .093 & .009 & \\
\hline \multirow{6}{*}{$\begin{array}{l}\text { Group } \\
\text { Gender }\end{array}$} & * & MUSICAL & 150.034 & & 2 & 75.017 & .407 & .666 & .003 & \\
\hline & & KINESTHETIC & 997.744 & & 2 & 498.872 & 2.961 & .053 & .020 & \\
\hline & & MATH / LOGIC & 155.327 & & 2 & 77.663 & .429 & .651 & .003 & \\
\hline & & SPATIAL & 588.097 & & 2 & 294.048 & 1.537 & .217 & .010 & \\
\hline & & LINGUISTIC & 622.423 & & 2 & 311.212 & 2.295 & .103 & .015 & \\
\hline & & INTERPERSONAL & 218.472 & & 2 & 109.236 & .626 & .535 & .004 & \\
\hline
\end{tabular}




$\begin{array}{lllllll}\text { INTRAPERSONAL } & 128.208 & 2 & 64.104 & .278 & .757 & .002 \\ \text { NATURALISTIC } & 329.272 & 2 & 164.636 & .724 & .485 & .005\end{array}$

Table 7. LSD Pairwise comparisons of MI at different proficiency levels

\begin{tabular}{llllll}
\hline Dependent Variable & (I) Group & (J) Group & Mean Difference (I-J) & Std. Error & Sig. \\
\hline \multirow{4}{*}{ Elementary } & Intermediate & $6.142^{*}$ & 1.930 & .002 \\
& & Advanced & $8.402^{*}$ & 1.893 & .000 \\
\cline { 2 - 6 } MUSICAL & \multirow{2}{*}{ Intermediate } & Elementary & $-6.142^{*}$ & 1.930 & .002 \\
& & Advanced & 2.260 & 1.966 & .251 \\
\cline { 2 - 6 } & \multirow{2}{*}{ Advanced } & Elementary & $-8.402^{*}$ & 1.893 & .000 \\
& & Intermediate & -2.260 & 1.966 & .251 \\
\hline
\end{tabular}

\section{Discussion}

\subsection{Responding to the Research Question One}

The findings revealed that there was a relationship between MI profiles and LLS used by Iranian EFL students. Akbari and Hosseini (2008) investigated the relationship between EFL learner's MI and strategy use. Also Hajhashemi, et al. (2011) investigated the relationship between LLS and MI. These results also support what Baş and Beyhan (2010) claimed about the important role of MI in language learning process.

Meanwhile, the findings of the present study are in line with the results of Hashemian and Adibpour's (2012) study in which there was a relationship between multiple intelligences and language learning strategies among thirty female EFL learners studying English as EFL in Iran.

Likewise, the results of Razmjoo, Sahragard and Sadri's (2009) study revealed that three vocabulary strategies (i.e. determination, social and memory strategies) had a significant relationship with several domains of MI. In addition, they found that linguistic intelligences made statistically significant contribution to the prediction of vocabulary learning knowledge.

On the other hand, the present study partially contrasts with Akbari and Talebinezhad's (2003) study in which there was a positive relationship between the use of LLS and students' proficiency scores. We found that there was no significant relationship among the participants' strategy use and their IQ scores.

\subsection{Responding to the Research Question Two}

There was a relationship between EFL learners' Multiple Intelligences (MI) scores and different proficiency levels. The findings of this study are in line with Pishghadam and Moafian's (2008) study in which there was a significant relationship between the success of teachers and their interpersonal, verbal-linguistic and musical-rhythmic intelligences. No significant relationship was found between their success and other types of intelligences. Moreover, it was found that there was no significant difference between gender and MI regarding the teaching success.

The findings of this study are in conflict with Pasha Sharifi's (2008) study in which there was a low to moderate but significant correlation among different kinds of intelligence and related school subject scores. Moreover, it was found that the female students were superior in intrapersonal intelligence while the male students were superior in visual-spatial intelligence and there was no significant difference between them regarding other intelligences.

The present study partially contrasts with Razmjoo's (2008) study which reported that there was no significant relationship between language proficiency and multiple intelligences. Also, no significant difference was found among male and female students and their MI and language proficiency. Bemani Naieni and Pandain (2010) also reported no significant relationship between MI, listening proficiency and motivational orientation among Iranian TEFL university students.

There are many issues regarding LLS yet need to be resolved. A variety of individual difference factors can affect the quality and quantity of L2 learners' strategy use. Therefore, for having successful strategy use, it seems necessary to take individual differences into consideration. Results showed that there were a meaningful and positive relationship between the learners' MI and their L2 strategy use. So, more intelligent EFL learners tended to use more language learning strategies. There was positive relationship between multiple intelligences and L2 


\section{(i.e. English) proficiency.}

This study was limited to Institutional setting. Therefore, the generalization beyond this should be undertaken with caution. Next, it is possible that identified learning strategies and multiple intelligences might be influenced by other variables such as nationality, age, field of study, etc. Finally, there was a limitation in using questionnaires to elicit language learning strategies and MI profiles. It could be supplemented with other research tools and techniques such as interviews, written diaries and other methods.

\section{References}

Abu Shmais, W. (2003). Language learning strategy in Palestine. TESL-EJ, 7(2), 20-33.

Akbari, R., \& Hosseini, K. (2008). Multiple intelligences and language learning strategies. System, 36(2), 141-155. https://doi.org/10.1016/j.system.2007.09.008

Akbari, R., \& Talebinezhad, M. R. (2003). The relationship between the use of language learning strategies by Iranian learners of English, their foreign language proficiency, and the learners' IQ scores. IJAL, 6(1), 1-20.

Aliakbari, M., \& Hayatzadeh, A. (2008). Variation of language strategies among Iranian English students: The effect of gender. International Journal of Pedagogies and Learning, 4(3), 72-87. https://doi.org/10.5172/ijpl.4.3.72

Armstrong, T. (2000). Multiple Intelligences in the classroom. Washington D C: Association of School Curriculum Development.

Baş, G., \& Beyhan, ö. (2010). Effects of multiple intelligences supported project-based learning on students' achievement levels and attitudes towards English lesson. International Electronic Journal of Elementary Education, 2(3), 365-388.

Bemani Naeini, M., \& Pandian, A. (2010). On the Relationship of Multiple Intelligences with Listening Proficiency and Attitudes Among Iranian TEFL University Students. TESL Canada Journal, 28(1), 97- 114. https://doi.org/10.18806/tesl.v28i1.1062

Canale, M. (1983). From communicative competence to communicative language pedagogy. In J. C. Richards, \& R. Schmidt (Eds.), Language and communication. London: Longman Group.

Chen, M. -L. (2009). Influence of grade level on perceptual learning style preferences and language learning strategies of Taiwanese English as a foreign language learners. Learning and Individual Differences, 19, 304-308. https://doi.org/10.1016/j.lindif.2009.02.004

Ehrman, M., \& Oxford, R. (1989). Effects of sex differences, career choice, and psychological type on adult language learning strategies. Modern Language Journal, 73, 1-13. https://doi.org/10.1111/j.1540-4781.1989.tb05302.x

Flower, W., \& Coe, N. (1976). Nelson English language Tests. Great Britain: Bluter \& Tannner Ltd, Frome and London.

Gardner, H. (1993). Frames of mind: the theory of multiple intelligences (2nd paper ed.). New York: Basic Books.

Gardner, H. (1995). Are there additional intelligences? The case for the naturalist intelligence: Howard Project Zero. Cambridge, MA: President Fellows of Howard College.

Gardner, H. (1998). A Multiplicity of Intelligences. Scientific American, 9(4), 18-23.

Gardner, H. (1999). Intelligence reframed. New York: Basic Books.

Gardner, H. (2007). Five Minds for the Future. Boston, MA: Harvard Business School Press.

Grainger, P. (2005). Second language learning strategies and Japanese: Does orthography make a difference? System, 33, 327-339. https://doi.org/10.1016/j.system.2005.01.003

Green, J. M., \& Oxford, R. (1995). A closer look at learning strategies, L2 proficiency, and gender. TESOL Quarterly, 29 (2), 261-297. https://doi.org/10.2307/3587625

Griffiths, C. (2003). Patterns of language learning strategy use. System, 31, 367-383. https://doi.org/10.1016/S0346-251X(03)00048-4

Hajhashemi, K., Parasteh Ghombavani, F., \& Yazdi Amirkhiz, S. Y. (2011). The relationship between Iranian EFL high school students' multiple intelligence scores and their use of learning strategies. English Language Teaching, 4(3), 214-222. https://doi.org/10.5539/elt.v4n3p214

Hashemian, M., \& Adibpour, M. (2012). Relationship between Iranian L2 learners multiple intelligences and 
language learning strategies. $R A L S, 3(1), 25-43$.

Kagan, S., \& Kagan, M. (1998). Multiple Intelligences: The Complete Multiple Intelligences Book. California: Kagan Cooperative Learning.

Khamkhien, A. (2010). Factors affecting language learning strategy reported usage by Thai and Vietnamese EFL learners. Electronic Journal of Foreign Language Teaching, 7(1), 66-85.

Leavell, A. G., \& Hong-Nam, K. (2006). Language learning strategy use of ESL students in an intensive English learning context. System, 34, 399-415. https://doi.org/10.1016/j.system.2006.02.002

Magogwe, J. M., \& Oliver, R. (2007).The relationship between language learning strategies, proficiency, age and self-efficacy beliefs: A study of language learners in Botswana. System, 35, 338-352. https://doi.org/10.1016/j.system.2007.01.003

O’Malley, J. M., \& Chamot, A. U. (1990). Learning strategies in second language acquisition. New York: Cambridge University Press. https://doi.org/10.1017/CBO9781139524490

Oxford, R. L. (1990). Language learning strategies: What every teacher should know. Boston: Heinle \& Heinle.

Oxford, R. L., \& Crookal, D. (1989). Research on language learning strategies: methods, findings and instructional implications. Modern Language Journal, 73, 404-419. https://doi.org/10.1111/j.1540-4781.1989.tb05321.x

Pasha Sharifi, H. (2008).The introductory study of Gardner's multiple intelligence theory, in the field of lesson subjects and the students' compatibility. Quarterly Journal of Educational Innovations, 24, 11-20.

Peacock, M., \& Ho, B. (2003). Student language learning strategies across eight disciplines. International Journal of Applied Linguistics, 13(2), 179-200. https://doi.org/10.1111/1473-4192.00043

Pishghadam, R., \& Moafian, F. (2008). The relationship between Iranian EFL teachers' multiple intelligences and their successful teaching in language institutes. Quarterly Journal of Humanities Alzahra University, $18(72), 101-121$.

Razmjoo, S. A. (2008). On the relationship between multiple intelligences and language proficiency. The Reading Matrix, 8(2), 155-174.

Razmjoo, S. A., Sahragard, R., \& Sadri, M. (2009). On the relationship between multiple intelligences, vocabulary learning knowledge and vocabulary learning strategies among the Iranian EFL learners. The Iranian EFL Journal Quarterly, 3, 82-110.

Rezaei, A. A., \& Almasian, M. (2007). Creativity, language learning strategies and language proficiency [Special issue]. Pazhuhesh-e Zabanha-ye Khareji, 32, 65-76.

Shearer, C. B. (1994). The MIDAS: A professional manuals. Kent, OH: MI Research and Consulting.

Smith, M. K. (2008). Howard Gardner and multiple intelligences, the encyclopedia of informal education. Retrieved on October 12, 2013 from http://www.infed.org/thinkers/gardner.htm

Tercanlioglu, L. (2004). Exploring gender effect on adult foreign language learning strategies. Issues in Educational Research, 14(2), 181-193.

Wharton, G. (2000). Language learning strategy use of bilingual foreign language learners in Singapore. Language Learning, 50(2), 203-243. https://doi.org/10.1111/0023-8333.00117

Young, D. J., \& Oxford, R. (1997). A gender-related analysis of strategies used to process input in the native language and a foreign language. Applied Language Learning, 8, 43-73.

\section{Copyrights}

Copyright for this article is retained by the author(s), with first publication rights granted to the journal.

This is an open-access article distributed under the terms and conditions of the Creative Commons Attribution license (http://creativecommons.org/licenses/by/4.0/). 